$0-401$

進行精柴腫愫に対する化学境法の 精果機能に及ほす影签

京都大学1）関西医大 ${ }^{2)}$ - 倉數中央 ${ }^{3)} \cdot$ 京都市立 ${ }^{4)}$

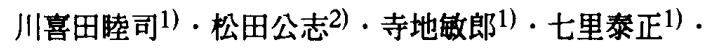
奥野博1) - 六車光英2) - 荒井陽一3) - 飛田収一4) . 岡田裕作 ${ }^{1)}$. 吉田修1)

【目的】シスプラチンを中心とした化学療法により 精巣腫場の予後は著しく向上した。そこで長期生存例 にとって問題となるのが好孕性である。今回シスプラ チンを含む化学療法で治療した進行精巣腫鹊患者の精 巣機能について検討したので報告する。

【対象と方法】京都大学および関西医大で治療した 進行精巣腫場55例の血中FSHと Testosteroneを測定し、 26例で精液検查を施行した。

【結果】 $400 \mathrm{mg} / \mathrm{m}^{2}$ 以上のシスプラチンで治療した 症例のFSH（平均 $35.6 \mathrm{mIU} / \mathrm{ml}$ ) は $400 \mathrm{mg} / \mathrm{m}^{2}$ 以下で治 療した症例のFSH $(19.9 \mathrm{mIU} / \mathrm{ml})$ より高值であった。 精液検査では、 $400 \mathrm{mg} / \mathrm{m}^{2}$ 以下で治療した20例のうち 14例 (70\%) が治療終了後平均 2.8 年で精子浱度が $20 \times 10^{6} / \mathrm{ml}$ 以上に回復したのに対し、 $400 \mathrm{mg} / \mathrm{m}^{2}$ 以上で 治療した6例では1例も精子濃度の回復を認めなかった。 精子浱度が改善した14例のうち 7 例が挙児を得た。

Testosteroneには変化を認めなかった。

【結語】 進行精巣腫場に対する3ないし4コースを超 える化学療法は造精機能に対し不可逆的な影響を及ぼ すものと思われる。

\section{O-403 G-C S F 単独前処置による末試み血幹細胞採} 順天堂大学泌尿器科 1) ・ 同輸血学研究室 2)

花澤喜三郎、小泉和夫、荻島達也、石井義之、渡遥良太、 指出一彦、長尾慶治、本田真一、磯部英行、藤田和彦、藤 目 真 1)、照屋 純、湯浅丟治 2)

【目的】進行した精巣腫瘍に対し未梢血幹細胞移植を併用 した超大量化学療法が施行されているが、多くの場合前処 置として化学療法が施行されている。しかし、最近健常者 では $\mathrm{G}-\mathrm{C}$ S F のみで大量の幹細胞を末梢血中に動員でき ることが判明しており、G-C S F 単独の前処置も施行さ れている。今回、我々は $\mathrm{G}-\mathrm{C} S \mathrm{~S}$ 単独前処置にて 3 例の 精巣腫場患者に末梢血幹細胞採取を施行したので報告寸る。

【対象及び方法】症例は精巣腫瘍患者 3 例で、年齢は 26 、 $56 、 62$ 歳。3 例とも化学療法を $5 、 2 、 3$ クール施行され ているが、放射線療法は施行されていない。採取方法は $\mathrm{G}$ -C S F (lenograstim) $500 \mu \mathrm{g}$ を 1 日 2 回に分けて皮下 注を6 日間（day1-day6）施行。day4-day60 3 日間末梢血 幹細胞採取を施行した。【結果】各症例において計 3 回の 末梢血幹細胞採取の結果は、MNC の総量24.0, 25.9, $10.6 \times 10^{8} / \mathrm{kg} 、 C D 34$ 陽性細胞数 $0.75,1.4,0.79 \times 10^{6} / \mathrm{kg}$ 、 CFU-GM $0.84 ， 3.0 ， 0.25 \times 10^{5} / \mathrm{kg}$ であった。副作用とし ては血小板减少を 3 例に認め、内 2 例は血小板輸血を必要 とした。また、腰痛により鎮痛剤の投与を必要としたのは 1 例であった。【考察】G-C S F 単独前処置にて、既に 化学療法を数回経験している精巣腫瘍患者に対しても十分 量のMNCを採取できたが、CD34陽性細胞、CFU-GMは十分量 採取できない症例もみられ、今後 $\mathrm{G}-\mathrm{C} \mathrm{S} \mathrm{F}$ 投与量の增量 を検討する必要があると思われた。
O-402 進行性精巣腫痦における末梢血幹細胞移植併用 の検討

神戸大学

山田裕二、原勲、鄉司和男、玉田博、山中和樹、

田口 功、後藤章暢、武市佳純、岡田弘、荒川創 -

守殿貞夫

【目的】超大量化学療法時に末梢血幹細胞移植 (PBSCT) を併用することにより短期間に白血球数の回復を得るこ とが可能となった。しかしこのとき動貝された未梢血好 中球の機能に関しては未だ充分な検諳がなされていない。 今回我々はPBSCT併用超大量化学療法時におりる未梢IIIL 好中球機能の経時的推移を検討した。

【対象と方法】対象は1995年4月より1996年7月の間に光 科で治療した進行性精巣腫瘍患者5例である。これらに対 L、CBDCA $250 \mathrm{mg} / \mathrm{m}^{2} 、$ VP $16500 \mathrm{mg} / \mathrm{m}^{2}$ 、IFO $1.5 \mathrm{~g} / \mathrm{m}^{2}$ を 各5日間施行後8日自にPBSCTを行うPBSCT併用超头量化 学療法を計8コース施行した。各コースの化学療法施行前、 化学療法施行7日目、15日目、20日目、30日目に採血を行 w，好中球殺菌能はPMA(phobol myristate acetate)刺激によ り活性酸素産生能を有する好中球の比率を、また貪食能 はラテックス粒子を食食した好中球の比率を、各々flow cytometryを用いて測定した。

【結果】 PBSCTはCD34陽性細胞数として4.1〜16.0×

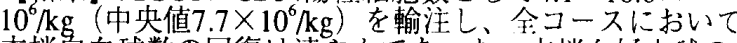
末梢白血球数の回復は速やかであった。本梢血好中球の 殺菌能は、化学璙法施行7日目 $(91.1 \pm 11.0 \%)$ に比べ15 旦貝には有意に低下したが $(51.4 \pm 33.0 \%, \mathrm{p}<0.05) 、 20$ 昌目には化学療法施行前値に回復し $(94.2 \pm 8.5 \%)$ その 後も同值を維持した $(96.3 \pm 3.1 \%) 。 一$ 方末梢血好中球 の貪食能は化学療法施行前值 $(84.3 \pm 16.9 \%)$ と比べ20 目、30日目にやや低下方る傾向を認めたが $(64.3 \pm 24.4 \%$ 、 $71.4 \pm 17.7 \%$ ）いづれも統計学的に有意ではなかった。

【結論】 PBSCT併用超大量化学療法を施行された進行性

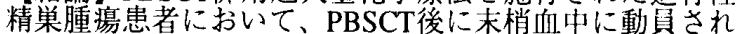
た好中球は正常な殺菌能、舍食能を有し、本潦法施行時 に十分その機能を果たしうると思われた。

\section{0-404 難治性肧細胞腪理に対する末梢血幹細胞} 東家矢科歯科大学

藤井靖久，木原和徳，辻井俊彦，石坆和博，影山幸雄，川上理， 有澤于鶴 大島博幸

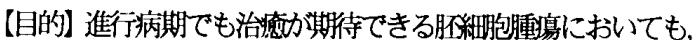
巨大車移や肝骨脸䡛移といった予後不良因子を有する症例や，寛 解後の再登症例に対しては, 通常の化学療法の効果には限界があ る. われわれは 1994 年以後, 難治例と考えられる症例ては first line としてVIP 療法を行い，1-2 コ一ス後にPBSC を採取して おいて，VIP 療法のみで寛解が期待できないと判定したら， PBSCT 併用大量化学療法を施行することを原則としている. 今 回，その有用性と安全性を検㶦した. [対象と方法] 難治例之考 えられ，VIP燎法後PBSC を和取した 5 例を対象とした年踰 は21-42歳で, 何れも non-seminoma である. 1 例は肺転移を 有する後腹膜原発性腺外肧細胞腫 4 例は精栄原発で Indiana Classification (IC) でadvanced 3 例, minimal 1 例である. 大 量化学療法は, VP-16 $1600-2400 \mathrm{mg} / \mathrm{m}^{2}$, IFM $6-10 \mathrm{~g} / \mathrm{m}^{2}$, $\mathrm{CBDCA} 1500 \mathrm{mg} / \mathrm{m}^{2}$ を原則とした. 【結果】全ての祉例で分 量のPBSC を採取できた。性腺外肧細抱腫には，PBSCTまたは 自家骨随移植を併用して, 通常よりは亮用量のVIP療法を施行し たが，部分寛解に留まり，その後病死した。ICでadvanœed の

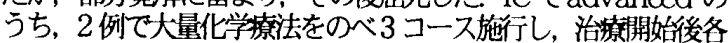
24,8 月で無病生存している. advanced の他の 1 例と minimal

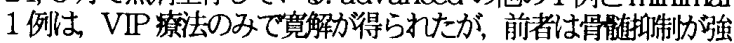
くPBSCTを行った. 大量化学療法 3コースで, PBSCT後白血 球数 $1000 / \mathrm{mm}^{3}$ を越えたのは 8-10 日，血小板輸血を要した期 間は，3-11 日 (45-80 単位) で，骨髄機能の回復は速やかであ

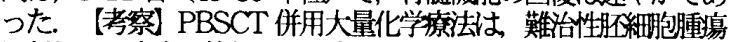
に対して，安全に施行でき，高い有效性があると考えられた。 た治療開始時において，PBSCTの準備をしておくことは，通常 の化学療法後の著明な骨能莇制に対しても施行できる点からも, 有用性加高い。 